\title{
DESAIN DAN IMPLEMENTASI MEDIA VIDEO PRINSIP- PRINSIP ALAT UKUR LISTRIK DAN ELEKTRONIKA
}

\author{
Boy Fechera, Maman Somantri, Dadang Lukman Hakim \\ Program Studi Pendidikan Teknik Elektro \\ FPTK Universitas Pendidikan Indonesia \\ Jl. Dr. Setiabudhi No.207 Bandung \\ email: boyfechera89@gmail.com
}

\begin{abstract}
Abstrak : Penelitian ini memaparkan tentang proses desain dan implementasi video pembelajaran dalam mempelajari prinsip-prinsip alat ukur listrik dan elektronika. Media ini dibuat dengan tujuan untuk meningkatkan pemahaman siswa terhadap prinsip-prinsip alat ukur listrik dan elektronika meliputi bahan ajar tentang alat ukur multimeter, voltmeter dan amperemeter. Prosedur penelitian mengikuti langkah-langkah penelitian pengembangan. Pengumpulan data dilakukan dengan pemberian kuersioner dan wawancara terstruktur. Hasil penelitian menunjukan bahwa kondisi pembelajaran masih bersifat konvensional, penggunaan media pembelajaran berbasis video telah diujicobakan dan berdampak positif terhadap respon belajar siswa serta membantu siswa dan guru dalam proses pembelajaran. Implikasinya diharapkan memberikan dampak terhadap peningktan inovasi guru dalam penggunaan media pembelajaran.
\end{abstract}

Kata kunci : amperemeter, media video, multimeter, voltmeter,.

\begin{abstract}
This study describes the design process and implementation of video media in learning the electrical and electronic measuring instruments principles. The purpose of making this media to improve students understanding of the principles of electrical and electronic measuring instruments, include teaching materials about the gauge multimeters, the voltmeter and amperemeter. Research procedure followed the steps of research and development. Data collection was done by assigning kuersioner and structured interviews. The results showed that the learning conditions is still conventional, the use of video-based learning media has been tested and positive impact on student responses and help students and teachers in the learning process. The implication is expected to have an impact on teachers increased innovation in the use of instructional media.
\end{abstract}

Keyword : amperemeters, multimeters, video media, voltmeters,.

\section{PENDAHULUAN}

Tercapainya tujuan pendidikan tidak terlepas dari adanya pengembangan di bidang pendidikan antara lain meliputi proses pembelajaran, media pembelajaran, pengadaan dan pengelolaan sarana dan prasarana, dan sebagainya. Berkaitan dengan pengembangan pendidikan tersebut, seorang guru dituntut agar memiliki pengetahuan mengenai inovasi dalam pembelajaran. Inovasi tersebut dimaksudkan agar kegiatan belajar mengajar lebih baik dan lebih menarik, sehingga dalam proses pembelajaran 
peran guru sangat penting dalam melaksanakan kegiatan belajar mengajar. Oleh karena itu, seorang guru dapat membuat siswa menjadi lebih bersemangat untuk mengikuti kegiatan pembelajaran tersebut, dan pada gilirannya berdampak positif terhadap hasil belajarnya.

Sekolah Menengah Kejuruan Negeri 12 Bandung merupakan salah satu SMK kelompok teknologi dan industri diharapkan mampu menghasilkan sumber daya manusia berkualitas dan siap pakai di dunia industri. Banyak mata pelajaran mendukung agar siswa lulusannya berkualitas dan siap terjun di dunia industri.

Dari hasil pengamatan selama melakukan Progam Latihan Profesi (PLP) di SMK Negeri 12 Bandung, terdapat mata diklat dimana siswa memiliki kesulitan dalam memahami materi pembelajaran. Mata diklat tersebut adalah mata diklat Mengukur Alat Ukur Listrik dan Elektronika (MAULE). Dan karakteristik siswa pada proses pembalajaran mata diklat tersebut cenderung malu bertanya bila menghadapi kesulitan dalam proses pembelajaran atau belum memahami materi pelajaran. Dan hal tersebut, menyebabkan kurangnya respon positif siswa terhadap mata diklat MAULE.

Berdasarkan permasalahan diatas, diperlukan suatu solusi untuk memecahkan permasalahan tersebut. Salah satu solusi untuk memecahkan permasalah tersebut adalah melakukan perubahan pada proses pembelajaran, yaitu dengan penggunaan media pembelajaran alternatif atau berbeda dari biasanya.

Media audio visual mempunyai kemampuan yang lebih baik dibandingkan media pembelajaran yang lain karena meliputi media auditif dan visual. Media video pembelajaran selain digunakan oleh guru pada proses pembelajaran, media video juga dapat dimanfaatkan oleh siswa untuk mengulang kembali materi yang sudah diberikan. Selain itu kelebihan media video dapat kapan saja dan dimana saja diputar oleh siswa, dengan syarat adanya media yang mendukung untuk menayangkan video tersebut. Selain itu media video juga dapat digunakan berulang-ulang kali dan media video dapat dimanfaatkan pada jangka waktu yang panjang dalam proses pembelajaran selama isi dari media video tersebut masih relevan dengan materi yang ada (Sudirman, 1992). Berdasarkan pernyataan dan kelebihan-kelebihan mengenai 
media video pembelajaran, maka penulis memilih media video pembelajaran sebagai solusi dari permasalahan tersebut. Dan diperlukan suatu kajian yang lebih mendalam mengenai peran video pembelajaran yang akan digunakan pada proses pembelajaran.

\section{METODE}

Penelitian ini dilakukan dengan menggunakan metode penelitian dan pengembangan, dengan langkah-langkah seperti ditunjukkan pada gambar 1 .

\section{TAHAP STUDI PENDAHULUAN}

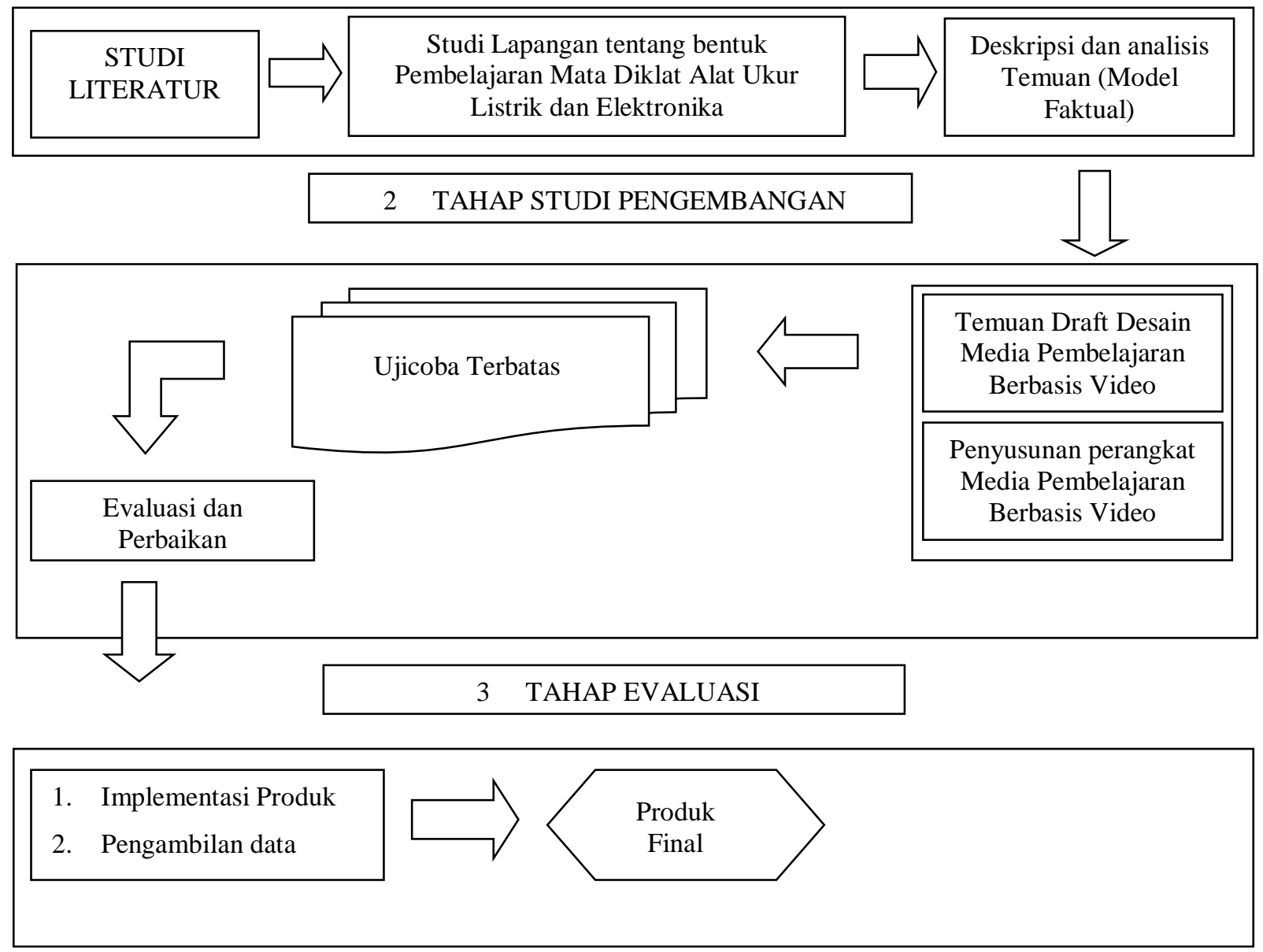

Gambar 1. Skematik Tahap-Tahap Penelitian Research and Development (Sugiyono, 2011)

Prosedur penelitian ini dapat dijelaskan sebagai berikut : 
1. Tahap Studi Pendahuluan; merupakan tahap prasurvey (tahap awal), dimana kegiatan yang dilakukan adalah sebagai berikut : (a) mengkaji teori-teori yang berkaitan dengan pembelajaran dengan penggunaan video pembelajaran, (b) mengkaji hasil-hasil penelitian terdahulu yang berkaitan erat dengan pembelajaran dengan penggunaan video pembelajaran (c) melakukan studi lapangan untuk mengetahui gambaran umum berkaitan dengan kurikulum yang digunakan, proses pembelajaran yang sedang berlangsung, sarana, dan fasilitas pembelajaran yang mendukung.

2. Tahap Studi Pengembangan, kegiatan yang dilakukan pada tahap kedua ini adalah meliputi: (a) perencanaan media, seperti : pengembangan materi, penyusunan flowchart dan skenario; (b) pengembangan draft awal, (c) meminta saran dan pendapat guru yang menguasai bidang alat ukur listrik dan elektronika, murid, dan dosen ahli (d) ujicoba terbatas (e) evaluasi dan perbaikan.

3. Tahap Evaluasi, pada tahap ini dilakukan: (a) implementasi produk, (b) pengambilan data dan (c) perolehan produk final.

\section{HASIL PENELITIAN}

\section{Kondisi Pembelajaran Mengukur Alat Ukur Listrik dan Elektronika (MAULE) di SMK Negeri 12 Bandung}

Kondisi pembelajaran MAULE yang tergambar dari hasil temuan studi pendahuluan yang dilakukan oleh peneliti memperlihatkan adanya permasalahanpermasalahan yang terjadi dalam pembelajaran. Permasalahan tersebut adalah minat siswa yang didominasi oleh tingkat yang cukup terhadap mata pelajaran Mengukur Alat Ukur Listrik dan Elektronika (cukup menyenangkan 48\%).

Pada pembahasan diatas mayoritas minat siswa terhadap mata pelajaran Mengukur Alat Ukur Listrik dan Elektronika ini hanya cukup menyenangkan dan ini bisa dikatakan kurang baik, karena hal ini dapat berpengaruh terhadap motivasi belajar siswa. Minat bisa dibilang berawal atau bagian dari motivasi dan itu bisa saja 
timbul dari pengaruh luar siswa. Jika dilihat dari hasil temuan studi awal alasan paling tidak menyukai pelajaran MAULE adalah karena pelajarannya susah (42\%), dan ini dikaitkan dengan penemuan lainnya yaitu penggunaan media yang jarang digunakan oleh guru (53\%). Sedangkan dari data lainnya menyebutkan bahwa siswa dapat lebih mudah memahami materi jika ada media pembelajaran (77\%).

Mengenai kondisi dan kinerja guru terdapat beberapa permasalahan yang berkaitan dengan kurangnya motivasi siswa, yaitu penggunaan media pembelajaran yang guru lakukan adalah berintensitas kurang. Selain intensitas penggunaan media jarang dan yang digunakan guru bila menggunakan media berupa alat peraga dan benda nyata saja, mungkin ini salah satu penyebab kurangnya motivasi belajar siswa.

Penggunaan media pembelajaran dirasa dapat menjadi alternatif pemecahan permasalahan yang didapat dari hasil penelitian tentang kondisi pembelajaran. Penggunaan media video dipilih menjadi media alternatif yang harus dicoba dalam pembelajaran MAULE dikarenakan media video tidak pernah digunakan oleh guru sebagai media pembelajaran. Pernyataan ini di dapat dari hasil angket yang diberikan kepada siswa tentang kondisi pembelajaran. Pembuatan media video diharapkan akan menjadi solusi dari permasalah yang ada.

\section{Pengembangan Video Pembelajaran}

Untuk menghasilkan video pembelajaran yang baik maka proses produksi harus melalui beberapa tahap proses kerja. Adapun kendala dari pembuatan video ini adalah penulisan skenario, pengambilan gambar, proses editing, uji ahli dibidang media dan isi. Pada pembuatan skenario video pembelajaran ini kesulitannya adalah harus memperhatikan beberapa hal yang akhirnya akan menghasilkan skenario yang sesuai dengan materi pembelajaran. Dalam pembuatan skenario video pembelajaran yang harus diperhatikan adalah kesesuaian video pembelajaran dengan RPP yang ada.

Kendala yang dialami dalam pembuatan skenario pembelajaran ini adalah kesulitan saat pembuatan bahasa narasi, dikarenakan narasi yang dibuat harus menggunakan bahas interaktif, tidak kaku dan bukan merupakan bahasa tulisan. Oleh pembuatan skenario memakan waktu yang cukup lama. Setelah pembuatan skenario 
selesai selanjutnya adalah pembuatan storyboard. Pembuatan storyboard bertujuan untuk menjelaskan gambar yang akan diambil. Storyboard selanjutnya dibuat berdasarkan scene-scene secara garis besar tentang isi video pembelajaran ini. Pembuatan storyboard ini bersamaan dengan pembuatan scenario yang sifatnya dapat berubah sesuai dengan video yang akan dibuat sebagai pembelajaran. Setelah pembuatan skenario selesai hal yang dilakukan adalah melakukan pengambilan gambar.

Pada proses pengambilan gambar diperlukan tempat yang dapat menunjang hasil video pembelajaran, tempat yang cukup kondusif dalam arti menunjang dalam proses pengambilan gambar dan percobaan pengukuran diperlukan agar didapatkan hasil yang maksimal. Cukup sulit untuk mendapatkan tempat yang baik dan cocok dalam proses pembuatan video pembelajaran ini. Pertama upaya peneliti mengatasi masalah ini dilakukan dengan pengambilan gambar di tempat laboratorium pengukuran yang ada disekolah dan dikarenakan tempat yang kurang kondusif saat pengambilan gambar dilakukan maka pengambilan gambar selanjutnya dilakukan di laboratorium JPTE UPI.

Produk media video pembelajaran ini, dibentuk dalam format .IFO dimana pada proses pembuatannya video ini menggunakan bantuan dua buah software yaitu software iMovie 9 dan Adobe Premier Elements 4. yang dalam proses pembuatan video pembelajaran ini berfungsi sebagai software pemindahan (capture) hasil gambar dari handycamp ke laptop yang digunakan untuk melakukan proses editing lebih lanjut dan sampai terciptanya video pembelajaran ini.

Hasil video pembelajaran ini selain digunakan pada proses pembelajaran disekolah. Video pembelajaran ini juga di upload ke media sosial YouTube dengan tujuannya bisa dimanfaatkan oleh lebih banyak orang dengan cara mengaksesnya di media sosial YouTube. Saat di upload ke YouTube video pembelajaran ini tidak dengan format .IFO dikarnakan tidak support karena terlalu besar kapasitasnya, jadi saat di upload video pembelajaran ini rubah dengan format MP4 (.m4v) dan penayangan video pembelajaran ini harus dibagi-bagi sesuai judul atau tayangan apa yang akan diperlihatkan agar memudahkan pengguna dalam memilih dan milihat 
video pembelajaran ini dan memperkecil kapasitas video pembelajaran yang akan di upload selain itu agar video pembelajaran ini support pada saat di upload ke media sosial YouTube. Berikut yang ditunjukan pada gambar 2 salah satu gambar video pembelajaran yang di upload dimedia sosial YouTube:

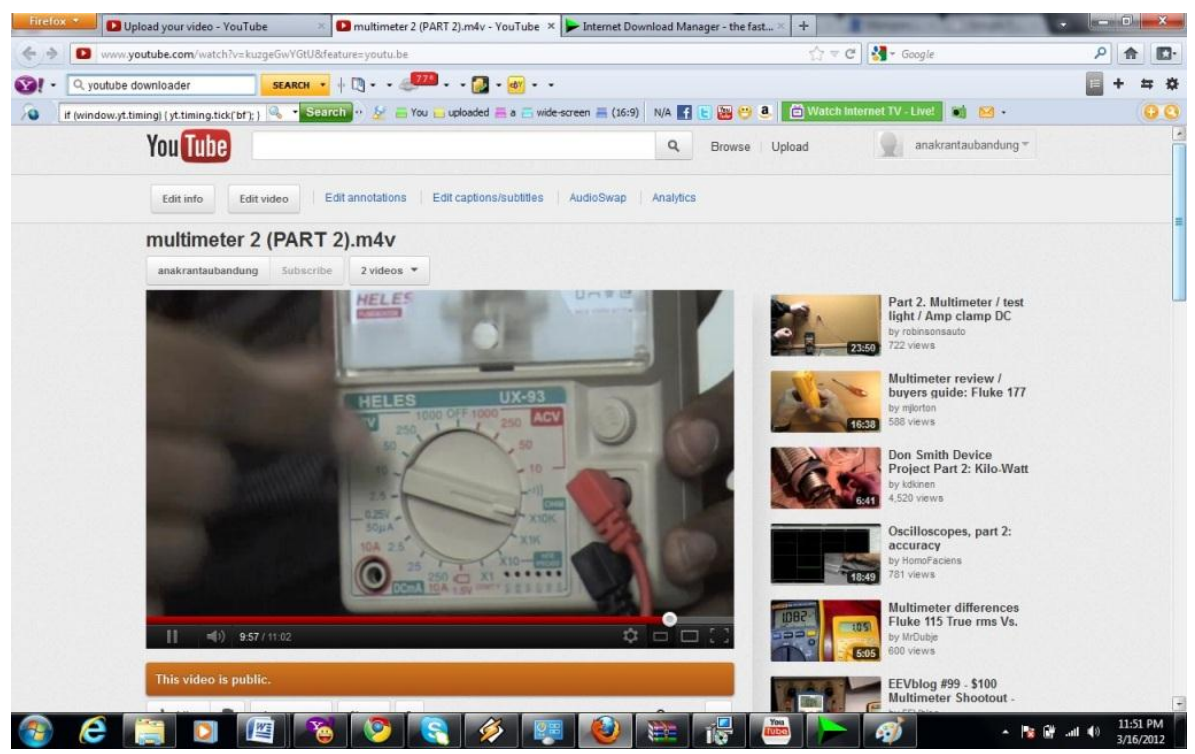

Gambar 2. Tampilan Video Pembelajaran Pada Media Sosial YouTube

Media pembelajaran ini dikemas dalam bentuk DVD (Digital Video Disc) dan terdiri atas tiga buah video pembelajaran. Dikarenakan materi yang diangkat pada video pembelajaran ini terdiri dari tiga buah materi yang berbeda, yaitu materi tentang multimeter, amperemeter dan voltmeter. Total durasi video pembelajaran ini adalah 1 jam 21 menit 38 detik. Yang terdiri dari video pembelajaran multimeter dengan durasi 55 menit 52 detik, Video pembelajaran amperemeter 14 menit dan video pembelajaran voltmeter 11 menit 26 detik. Dan total besar kapasitas video pembelajaran ini adalah 4,32 GB yang terdiri dari video pembelajaran multimeter sebesar 3,18 GB, video pembelajaran amperemeter sebesar $472 \mathrm{MB}$ dan video pembelajaran voltmeter sebesar $690 \mathrm{MB}$.

Adapun kekurangan dan kelebihan dari media ini adalah sebagai berikut: $\$

1. Kekurangan

a. Memerlukan waktu yang cukup panjang pada proses pembuatan sampai terciptanya video pembelajaran. 
b. Memerlukan biaya yang cukup besar untuk keperluan pembuatan video pembelajaran.

c. Hanya dapat dipergunakan dengan bantuan media komputer/leptop dan memerlukan bantuan infokus/proyektor dan speaker saat digunakan pada proses pembelajaran di kelas.

2. Kelebihan

a. Membantu siswa dalam memahami materi pelajaran.

b. Membantu guru dalam proses pembelajaran.

c. Media pembelajaran yang simpel dan menyenangkan.

d. Video pembelajaran juga dapat dimanfaat oleh masyarakat luas, dengan cara mengaksesnya di media sosial YouTube.

e. Media ini dapat dipakai dalam jangka waktu yang panjang dan kapanpun jika materi yang terdapat dalam video ini masih relevan dengan materi yang ada

\section{PEMBAHASAN}

Berdasarkan data yang diperoleh dari angket sebagian besar siswa dan guru berpendapat positif tentang media pembelajaran ini. Adapun pendapat siswa mengenai media video pembelajaran ini mayoritas menyatakan bahwa dengan menggunakan video pembelajaran membuatnya termotifasi dalam belajar. Dan sebanyak $84 \%$ siswa menyatakan bahwa media video merupakan media pembelajaran yang menarik. Hal ini tergambarkan bahwa penggunaan media video dapat menarik antusias siswa serta motifasi belajar siswa.

Dengan menyaksikan media video pembelajaran siswa juga sudah dapat memahami fungsi dan cara penggunaan alat ukur yang ditayangkan dalam media video tersebut. Salah satunya dapat digambarkan dari pernyataan mayoritas siswa sebanyak $75 \%$ yang berpendapat bahwa materi yang terdapat pada video pembelajaran multimeter sudah dapat membuatnya mengerti fungsi dari multimeter dan $78 \%$ menyatakan percobaan atau praktek dalam video pembelajaran multimeter membuatnya paham tentang cara penggunaan multimeter. Dapat disimpulkan bahwa 
penggunaan media video dapat membantu siswa dalam memahami materi dalam proses pembelajaran.

Siswa juga berpendapat mengenai kejelasan penyajian materi dalam video pembelajaran ini. Dalam angket juga ditanyakan mengenai kejelasan audio/suara pada video pembelajaran ini dan mayoritas siswa sebanyak 60\% menyatakan sudah jelas. Selain itu, sebanyak $72 \%$ siswa juga berpendapat bahwa gambar pada video ini juga sudah terlihat jelas. Dan sebanyak 91\% Siswa juga berpendapat bahwa Title/judul dalam video ini dapat memperjelas mempercobaan dan penjelasan yang akan ditampilkan. Hal ini menyatakan bahwa media video ini sudah dapat dikatakan layak untuk dijadikan standar video pembelajaran yang baik menurut pandangan siswa.

Dalam angket implementasi video pembelajaran ini. Ditanyakan juga mengenai hal mengenai apakah perlu penggunaan media video dalam setiap pembelajaran MAULE. Ternyata mayoritas siswa sebanyak 75\% menyatakan perlu. Hal ini mengidentifikasikan bahwa media video dapat dijadikan salah satu media alternatif dalam proses pembelajaran yang diinginkan siswa.

Sejalan dengan keinginan siswa, dalam angket semua guru menyatakan video pembelajaran ini diperlukan untuk membantu dalam proses pembelajaran selain itu guru juga menyatakan bahwa video pembelajaran ini membantu siswa dalam memahami materi pembelajaran. Dan semua guru menyatakan niatnya untuk menggunakan media video dalam proses pembelajaran dan hal ini bisa saja dikarenakan dari pernyataan semua guru yang menyatakan bahwa media video ini memudahkan dalam mengajarkan materi pelajaran.

Dalam angket yang diberikan kepada guru juga ditanyakan mengenai hal-hal yang berkaitan tentang kejelasan penyajian materi. Dan pada poin ini semua guru menyatakan bahwa gambar dalam video pembelajaran ini sudah jelas dan audio/suara pada video pembelajaran ini sudah jelas selain itu penggunaan teks dalam video pembelajaran ini membantu memahami isi dari video pembelajaran. Tetapi dalam penyajian materi dalam media video pembelajaran ini hanya dua orang guru yang menyatakan menarik dan satu orang guru menyatakan kurang menarik. 
Berdasarkan data dari angket, semua guru juga menyatakan bahwa video pembelajaran ini sudah sesuai dengan materi yang disampaikan. Dan menyatakan bahwa media video pembelajaran ini sesuai dengan karakteristik peserta didik. Serta media video ini mudah dimengerti/dipahami oleh peserta didik.

Menurut pendapat guru media video merupakan media pembelajaran yang menarik antusias siswa dalam belajar. Hal bisa dikarenakan media video adalah media pembelajaran yang baru dalam proses pembelajaran pada mata pelajaran Mengukur Alat Ukur Listrik dan Elektronika. Dan diharapkan penggunaan media video menjadi media alternatif dalam proses pembelajaran dan menjadi solusi dari permasalahan minat belajar siswa.

\section{KESIMPULAN}

Berdasarkan hasil penelitian yang diperoleh selama penelitian dan pengembangan Media pembelajaran Berbasis Video mengenai Alat Ukur Listrik dan Elektronika di SMK Negeri 12 Bandung, dikemukakan beberapa kesimpulan sebagai berikut:

1. Kondisi pembelajaran yang berlangsung sebelumnya pada mata pelajaran Mengukur Alat Ukur Listrik dan Elektronika ini khususnya di SMK Negeri 12 Bandung diperoleh dari hasil studi pendahuluan yang berdasarkan pada sudut pandang siswa, guru. Siswa memiliki minat yang cukup terhadap mata pelajaran Mengukur Alat Ukur Listrik dan Elektronika. Karena minat dan motivasi merupakan salah satu faktor penting dalam proses pembelajaran, maka agar dapat meningkatkan ketertarikan siswa terhadap mata pelajaran ini perlu adanya sesuatu yang baru yang dapat menjadi pemicu minat dan motivasi tersebut. Permasalahan yang terjadi bukan hanya pada faktor siswa saja, dari hasil temuan yang diperoleh ternyata guru jarang menggunakan media secara rutin. Hal ini bertolak belakang dengan karakteristik siswa yang lebih memahami materi jika menggunakan media pembelajaran.

2. Dalam pembuatan video pembelajaran tidaklah mudah dikarenakan harus melalui beberapa tahapan-tahapan yang harus dilalui dan memakan waktu yang cukup 
lama. Selain itu membutuhkan perlengkapan dan keahlian khusus untuk membuat sebuah video pembelajaran. Akan tetapi media video pembelajaran ini bisa dijadikan media alternatif dalam proses pembelajaran selain itu media video pembelajaran ini sangat praktis dalam penggunaan dan media ini mudah diperbanyak yang bertujuan agar dapat dimanfaatkan lebih banyak orang.

3. Dari hasil pengumpulan data pada angket guru dan siswa tentang kebergunaan video pembelajaran ini dapat diamsusikan :

a. Bahwa video pembelajaran ini dapat mempermudah dalam memahami materi pembelajaran dan bermanfaat dalam proses pembelajaran.

b. Penggunaan media video dalam proses pembelajaran sudah sesuai dengan kondisi siswa yang lebih memahami materi jika menggunakan media pembelajaran.

c. Kejelasan tampilan video pembelajaran ini secara keseluruhan sudah dapat dikatakan baik.

d. Dengan menggunakan media video siswa dapat disimpulkan bahwa penumbuhan minat belajar menjadi lebih meningkat.

\section{DAFTAR PUSTAKA}

Alwasilah, A.Chaedar (2011). Pokoknya kualitatif (edisi revisi VI). Jakarta: Pustaka Jaya

Arsyad, Azhar. (2011) Media Pembelajaran. Jakarta: Raja Grafindo

Daryanto.(2010). Media Pembelajaran. Yogyakarta: Gava Media

Firman, H.(2007). Penelitian Pendidikan Kimia. Bandung: Universitas Pendidikan Indonesia.

Gagne, Robert Mills and Briggs, Leslie J. (1979) Instructional technology: foundations, New Jarsey: Lwrence Erlbaum Associates Inc.

Heinich, et.al. (1985). Instructional Media \& New Technology of Instruction. New York: MacMillan Publishing. 
Liawati.(2006). Proses pembelajaran menggunakan video dalam menunjang kemampuan komunikasi berbicara bahasa inggris. Skripsi (Tidak diterbitkan). Bandung : UPI

Miarso, Y. (2004). Melayani Benih Teknologi Pendidikan. Jakarta: Kencana

Purwanto, M Ngalim. (2006). Prinsip-prinsip dan Teknik Evaluasi Pengajaran. Bandung : PT. Remaja Rosdakarya.

Sudirman N., dkk. (1992). Ilmu Pendidikan. Bandung : Rosda Karya.

Susilana, R \& Cepi R. (2008). Media pembelajaran. Bandung. Jurusan Kurikulum dan Teknologi Pendidikan. Bandung : UPI

Sugiyono. (2011). Metode Penelitian Kuantitatif Kualitatif dan R\&D. Bandung: Alfabeta 